\title{
Research on the Geography of Agricultural Change: redundant or revitalized?
}

\section{Morris* and N.J. Evans}

* Research Fellow, Countryside and Community Research Unit, Department of Countryside and Landscape, Cheltenham and Gloucester College of Higher Education, Francis Close Hall, Swindon Road, Cheltenham, GL50 4AZ, UK.

email CMorris@Chelt.ac.uk

Senior Lecturer in Geography, Department of Geography, University College Worcester, Henwick Grove, Worcester, WR2 6AJ, UK. emailn.evans@worc.ac.uk 


\section{Research on the Geography of Agricultural Change: redundant or revitalized?}

\section{Summary}

Future research directions for agricultural geography were the subject of debate in Area in the late 1980s. The subsequent application of political economy ideas undoubtedly revived interest in agricultural research. This paper argues that agricultural geography contains greater diversity than the dominant political economy discourse would suggest. It reviews 'other' areas of agricultural research on policy, post-productivism, people, culture and animals, presenting future suggestions for research. They should ensure that agricultural research continues revitalized rather than redundant into the next millennium.

\section{The redefinition of agricultural geography}

It is ten years since Bowler and Ilbery (1987) attempted to reinvigorate research into agricultural change through a 'redefinition' of agricultural geography in Area. Drawing upon earlier ideas about the political economy of agriculture expressed by Marsden et al. (1986) Bowler and Ilbery (1987)'s framework was an attempt to ensure that research into agriculture did not become a redundant area of academic attention. The cause of their concern at this point in time was that research topics examined by agricultural geographers concentrated on regional changes in farm inputs, farm-size structures, farm incomes and agricultural marketing. According to Bowler and Ilbery $(1987,327)$, these showed 'every signs of diminishing returns' and were attracting 'a declining number of researchers in all countries'. Atkins $(1988,281)$, in a comment on this article, went further by stating that agricultural geography had lost its way in an overconcentration on 'production functions and tedious typologies', emphasizing that food rather than farming should be central to research. A 'theoretical impasse' had become associated with such work, further explaining the timing of Bowler and Ilbery's (1987) paper. The emergence of new theoretical ideas in human geography offered potential relevance to explanations of changes in the agricultural sector. Indeed, they argued that 'There is now a need for agricultural geography to extend its theoretical base to encompass the structuralist perspectives of political economy' (Bowler and Ilbery, 1987, 329). Support for this dimension was forthcoming from Marsden (1988) who provided a more detailed critique of the 'problems and possibilities' of incorporating political economy perspectives into agricultural geography. An additional stimulus to Bowler and Ilbery's research agenda was that agriculture itself had entered a phase of policy uncertainty after a long period of stability. In the mid-1980s, the prevailing productivist ethos based on increasing food output was challenged by a political crisis consisting of interelated budgetary, production and environmental problems. This severely disrupted the traditional context for agricultural geography, but simultaneously opened up new avenues for research. Bowler and Ilbery (1987) suggested that research into agriculture be reorganised around three central components. First, the 'food chain' was advocated as sufficient in scope to provide an 'integrating conceptual framework' and a convenient way to explore the linkages between agricultural production and urban and industrial food systems. Secondly, from this platform, an extended theoretical base using political economy ideas could be developed. Thirdly, this in turn would provide a broader empirical content to agricultural research. It was hoped that such a 
redefinition would 're-establish a coherence currently lacking in research work and teaching' (Bowler and Ilbery, 1987, 330).

An important observation about Bowler and Ilbery's proposed framework was that political economy approaches were not introduced specifically to preserve institutionally-defined subareas such as agricultural geography. Instead, it was predicted that a 'blurring' of the boundaries of study would occur (Marsden, 1988). Political economy approaches attempted to provide better explanations of agricultural change and in so doing they demanded 'an interdisciplinary effort whereby the boundaries of sub-disciplines are progressively weakened' (Marsden, 1988, 320). This led researchers to look beyond the farm gate to understand the agricultural sector, leading subsequently to interaction with other disciplines and geographical sub-fields and extending the range of topics studied. This is illustrated clearly in the analysis of an increasingly globalised food system (McMichael, 1993; Whatmore, 1995; Le Heron and Roche, 1995, Marsden and Arce, 1995; Goodman and Watts, 1997). A profusion of research on agricultural issues adopting this approach has been forthcoming, ensuring a revitalization rather than a redundancy of academic interest, although little further debate has taken place about the nature of agricultural geography itself. However, political economy has become the dominant discourse to the extent that, for many, it has come to represent agricultural geography. This is reinforced in a host of recent reviews which equate explicitly the development of political economy ideas with agricultural geography (see Short, 1996; Whatmore et al., 1996; Marsden et al., 1996; Marsden, 1998a). An irony is that in this way political economy could be viewed as providing coherence in agricultural geography through a clearly defined theoretical position, as behaviouralist work and models of economic rent did before it, contributing to a reinforcement of the identify of agricultural geography as a distinct sub-field of inquiry.

The significance of the contribution of a political economy thesis in agriculture is unquestioned. Further, in its modified form it has increasingly striven to capture some appreciation of the 'diversity of social relations and cultural practices shaping accumulation and regulation' (Marsden et al., 1996, 362). However, consistently approaching an analysis of agricultural change from one theoretical position has tended to eclipse the rich variety of work on agricultural change existing alongside that adopting a political economy perspective. Consequently, work which makes no direct claim to be developing political economy ideas tends to fall beyond the remit of reviews of political economy which have dominated 'progress' reports on agricultural research (for a recent illustration, see Marsden, 1998a). Instead, it adopts a range of conceptual positions and it is this variety in research that offers strength and vitality to the study of agrarian issues. It also reflects a general shift within human geography away from the search for a single theoretical position and towards a diversity of narratives on research topics. Hence, one purpose of this paper is to review progress in this area of 'other' agricultural work and so give a voice to a range of discourses which provide different perspectives on agriculture to that of political economy. It may reasonably be expected that such perspectives would be included by those reviewing the considerable new dynamism to be found within rural geography. However, agricultural issues have received scant specific attention in these cases (see Cloke, 1997; Halfacree, 1997; Phillips, 1998). It is the intention here to capture some of the vibrancy and breadth of agricultural work and to highlight possible new research 'excitements' in agriculture to add to those made by Cloke (1997) in the rural realm. Both new research topics and new 
conceptual approaches to these topics are suggested, drawing upon relationships with the new theoretical advances made in rural geography, specific agricultural policy-led work, empirical analysis of farming trends, and wider engagement with human geography and related disciplines. The nature of the discussion, as Phillips (1998) recently acknowledges in a review of rural social geography, reflects the authors' own trajectory in academic study. One outcome of this is that attention is confined to agriculture in developed market economies and specific examples are primarily taken from the UK literature.

\section{'Other' agricultural research}

Using specific examples, this section seeks to demonstrate that research into agricultural change is far from redundant and that future prospects for academic work are bright. This can be revealed through a discussion of 'other' agricultural research which simultaneously reports on progress and illuminates further possibilities for research. Given the many opportunities that present themselves and limitations of space, selectivity is necessary so that the subsequent discussion is organised around three sub-headings. These are based upon volume of research interest generated, issues that have been highlighted but have yet to be fully explored, and those presenting novel and interesting research possibilities. First, a greatly neglected area in progress reviews is the considerable quantity of work undertaken on the evolution of agricultural policy. Secondly, an important element deriving from policy shifts has been the recent engagement of researchers with the concept of a 'post-productivist transition', a specific issue which is worthy of closer attention. Thirdly, a broad group of concerns offer refreshing perspectives on agricultural change for geographers, comprising continued development of issues surrounding people working in the agricultural sector and new ways of thinking about 'culture' and 'animals' emanating from elsewhere in human geography.

\section{The evolution of agrarian policy}

There is little doubt that there have been significant changes in agricultural policy since the mid1980s. Previously, there was a relative paucity of policy-oriented work within agricultural geography, that of Bowler (1979) being a major exception. This represented a rare spatial analysis of the adoption of specific policy measures by farmers (such as the hill cow subsidy and ploughing grant) and drew upon insights from a behavioural perspective. However, it is the scale of recent changes in agricultural policy that have stimulated a new genre of policy-related research. Work has been of two main kinds. First, research has taken a macro-policy view, investigating the nature and form of state intervention in agriculture, the implications of this intervention for the environment, and how national / European Union (EU) policy making has increasingly been shaped by international events and processes particularly GATT and WTO 1 (Bowers and Cheshire, 1983; Cox et al. 1986; Lowe et al., 1986; Bowler, 1989; Winter, 1996; Potter, 1998; Potter and Goodwin, 1998; Marsden, 1998a). Secondly, developments in agrienvironmental policy (AEP) have come to represent a particularly important focus for those interested in policy analysis. Here, research has critically examined the design of the agrienvironmental policies themselves (Potter, 1988; Baldock et al., 1990), but increasingly attention has been given to the implementation of these initiatives with the neatly defined spatial boundaries of many AEP schemes providing a convenient analytical focus. A significant tranche of studies has examined the impact of AEP on farmers, largely through investigation of the adoption process of individual agri-environmental schemes (Brotherton, 1991; McHenry, 1994; 
Whitby, 1994; Morris and Potter, 1995; Battershill and Gilg, 1996; Wilson, 1996; Morris and Young, 1997). Many of these build upon a behavioural tradition in agricultural geography by focusing on the decision-making processes of farmers. Although not always theoretically overt, the applied and policy-oriented work on agricultural and agri-environmental policy has made important conceptual and empirical contributions to agricultural geography alongside those of political economy, a fact which tends be overlooked in reviews of the latter. It has made a direct contribution to the development of agri-environmental initiatives by informing policy makers about the effectiveness of specific policy measures. Of wider significance than this, it has elucidated the processes by which farmers take on board environmental considerations.

It is evident that this work has made a positive contribution to the geography of agriculture, but three particular dissatisfactions can be observed. First, some agri-environmental schemes have received more research effort than others. This can be explained in part by the differential attention and financing given to individual schemes by government, especially as some schemes have been accorded a higher political profile than others (Evans and Morris, 1997). Also, there are difficulties associated with gaining access to schemes and their participants that do not have spatially delimited boundaries (Evans, 1997). Consideration of those schemes which have received less research effort would therefore be valuable. For example, there have yet to be reports of the agri-environmental aspects of Objective $5 \mathrm{~b}$ funded schemes, so this is a possible future development. Secondly, although it is important to appreciate local differences, highlighted by case study work such as that on specific Environmentally Sensitive Areas (ESAs), this approach to agri-environmental research has meant that different areas of environmental value have been considered largely in isolation from broader objectives of biodiversity, sustainability and future Common Agricultural Policy (CAP) reform. One cause of this problem is that some case study work on AEP has been derived from the monitoring and evaluation of individual agri-environmental schemes undertaken for state departments (Whitby, 1994). This has been critical of specific policy elements but weaker on fundamentally challenging this form of support for the environment. For example, Skerratt (1994) admits that work based on the Ministry of Agriculture, Fisheries and Food's (MAFF) evaluation of ESAs permitted only a particular view of ESA participants and their experience of participation. A lack of critical analysis can be viewed in the context of Murdoch and Ward's (1997) concept of governmentality. Rather than being lead by agricultural departments who are trying to implement policy, it would appear more pertinent to explore how the state has constructed agricultural and agri-environmental policy to regulate the sector. This has been clearly revealed in a discourse analysis of the 1992 agri-environment regulation adopted by J. Clark et al. (1997). Thirdly, although work on agri-environmental policy formulation by the state and its implementation at the farm level has progressed, there has been surprisingly little exploration of the way in which AEP is mediated. As Wilson (1997) suggests, clear possibilities exist for integrating actor network analyses into studies of AEP, helping to reveal something about the regulatory nature of the agencies involved (Cooper, 1998).

Agricultural policy changes will undoubtedly continue to inspire research into the effects of policy, particularly those initiatives which attempt to stimulate voluntarily 'greener' behaviour amongst members of the farming community (Morris and Potter, 1995). However, taking the wider view will also continue to be crucial, especially as the policy structures of the CAP come 
under further pressure from economic and other policy pressures both external and internal to the EU (Marsden, 1998a).

\section{The 'Post-productivist Transition'}

The changes in agricultural policy discussed above have increasingly been conceptualised as 'post-productivism'. The notion of a post-productive transition (PPT) emerged in the early 1990s to capture the change in agrarian priorities (primarily of the EU's CAP) away from food production towards meeting broader rural development and environmental objectives (Lowe et al., 1993; Bowler and Ilbery, 1993; Ward, 1993). The PPT should be a key development for geographers engaged in agricultural research, yet it possesses a curious dual role as a descriptor of work already undertaken and a focus for further analysis. More specifically, it can be argued that work on the PPT comprises three chronological research components. First, postproductivism was initially used to summarize aspects of agricultural adjustment which had previously and variously been conceptualised as 'survival and accumulation strategies', 'elements of farm adjustment' and 'farm business development paths' (see Marsden et al., 1989; Munton, 1990; Bowler, 1992 respectively). It represented a convenient way to acknowledge the differential responses made by farm households at the point of production to new conditions in the farm sector. Secondly, there has been a brief phase attempting to establish the characteristics of the PPT. According to Ilbery and Evans (1996), the remaining characteristics of the PPT encompasses: a shift in emphasis away from quantity towards quality in food production (Morris and Young, 1998; Marsden, 1998b); the growth of alternative farm enterprises, conceptualised as 'pluriactivity' (Ilbery, 1991; Evans and Ilbery, 1993); state efforts to encourage a return to more traditional, sustainable farming systems through agri-environmental policy (Wilson, 1996; Ilbery et al. 1997); the growing environmental regulation of agriculture (Robinson, 1991; Ward et al., 1995); and the progressive withdrawal of support for agriculture (Winter, 1996), this latter characteristic being predominantly relegated to a contextual position within agri-environmental research. Thirdly, the PPT has most recently become the subject of process-oriented theorization. Ilbery and Bowler (1998) view the PPT as a simple reversal of previous productivist components of change which emphasize extensification rather than intensification, dispersion rather than concentration and diversification rather than specialization. Such developments bring with them new regulatory conditions which again presents opportunities to utilise theoretical advances made in rural geography (for example, see G. Clark et al., 1997).

Perhaps unsurprisingly, the piecemeal amalgam of conceptual and empirical work represented by the PPT has failed to generate more searching questions. For example, there has been little debate about the usefulness of a conceptual division between 'productivism' and 'post-productivism' to summarize complex processes of agricultural change. Insights from work in rural geography (and elsewhere in the discipline) on 'Fordism' and 'post-Fordism' could be used to inform an evaluation of post-productivism (Cloke and Goodwin, 1992; Goodwin and Painter, 1996). In this case, it could be argued that the post-productivist transition is more appropriately viewed as encompassing a number of changes which accompany a predominantly productivist agriculture rather than a wholesale shift in the sector. Notions of structured coherence, as suggested by Cloke and Goodwin (1992, 326-327), may characterize the post-productivist transition as a 'whole series of movements between the differing practices and procedures of various strategies of regulation operating at overlapping scales'. This would aid analysis of a new 'mode of 
regulation' in agriculture, as Goodwin and Painter (1996) have suggested for industrial organization and local governance in preference to a post-Fordist model, and move research beyond descriptive cataloguing of these changes as simply fitting a 'post-productivist model'. Such an approach may help to overcome the unsatisfactory impression that 'post-productivism' represents the end of a productivist philosophy in agriculture when this is clearly not the case. Evidence shows that despite the reorientation of agricultural policy away from uni-dimensional food production, for most farmers it is 'business as usual' in meeting food output goals (Winter, 1997). Two diagnostic components of post-productivism, namely pluriactivity and agrienvironmental policy, both impact significantly only on a small number farming businesses, whilst environmental regulation (another component) remains a minor inconvenience in day-today farming practice. For example, in the late 1980s boom-time of on-farm diversification, only an estimated 6\% of farms had accommodation enterprises (the most popular type), and just a fraction generated significant income (see Evans and Ilbery, 1989 and 1992). Similarly, Potter and Goodwin (1998) demonstrate that current spending on agri-environmental policy is less than $4 \%$ of the agricultural budget. Further, many of these diagnostic activities are not new to the agricultural sector, with major enterprises such as farm-based accommodation being found as far back as the 19th Century (Bouquet, 1985). This is not to deny that the scale, number and variety of non-food productive activities has increased on farms since the mid-1980s, but to question whether an emphasis on these conditions is sufficient to represent a 'transition'. A potentially interesting debate about a 'post-productivist myth' has yet to establish itself in the literature.

\section{People, culture and animals}

The previous two sections have acknowledged the significant policy changes that have occurred in the agricultural sector and started to explore the way people respond to such shifts. However, important in 'other' agricultural research has been the specific focus on people in agriculture, and it is to this area of inquiry that the discussion now turns. It was in the 1970s that behavioural perspectives introduced the importance of individual farmers as decision-makers and established a strong agency orientation within agricultural research (Ilbery, 1985). The emphasis was predominantly on the process by which male farmers made economic decisions about 'their' farm business, divorced from external influences (those beyond the farm gate). Further, little consideration was given to the way farmers lived their lives in a broader sense, interacting with other people in the farm household. Political economy perspectives, which rejected the behavioural tradition, drew attention away from individual agents and the choices made within their decision-making processes towards the structures which constrain these choices. Conceptualised in the very different terms of modified political economy, agency was present but not central to analyses of agricultural change. For example, agency was incorporated into investigations of the 'strategies' that individual farm households were adopting to cope with falling farm incomes and changing policy, investigated empirically through farm interviews (Marsden et al., 1987; Marsden et al., 1989; Evans and Ilbery, 1992). Thus, the impact of political economy was to assist agricultural geographers in considering the 'people' of farm families and households, rather than the farmer alone, broadening the scope of analysis.

One developing thread of research on agricultural people has been the contribution of farm women to the farm business. An informal identification of farm women's worlds was achieved in the rural 'community studies' genre of research (Frankenburg, 1966; Harper, 1989). Although 
these studies provided sketches of the contribution of women to the functioning of farms, women were not central to these descriptions of rural life. The first detailed focus on women in agriculture was attempted by Gasson (1980) who identified a range of role types for women in farming. Building on this approach, Gasson then provided descriptive accounts of the farm wife's contribution to the farm household (Gasson, 1989). As the importance of the farm household in agriculture was more generally realised, research started to incorporate insights from work on gender relations emerging in mainstream human geography (Whatmore, 1991; Berlan-Darqué and Gasson, 1991). Farm women were investigated as one factor explaining the survival of the family farm in capitalist conditions as part of a reconstituted political economy in which gender relations were placed centre stage (Whatmore, 1991 and 1993). This was taken further through recognition of the farm family as a diverse unit of capital-labour relations within which actions and decisions derive from imbalances of power between farm men and women (Whatmore, 1991). Feminist perspectives were introduced to focus upon this relationship and its consequences for farm life. Despite this interest, specific theories of gender relations remain to be fully exploited in agricultural geography and considerable scope for feminist work within analyses of agricultural change exists. For example, it should be possible to conduct analyses of women farmers (independent of males) and those women directly inheriting farms in comparison with those marrying into farming, or to examine mainstream agricultural issues (such as the BSE crisis, the new emphasis on conservation in farming, farming suicides) from the farm women's perspective. Ironically, changes in agricultural policy have had the dual and contradictory effect of diverting attention away from farm women and helping to refocus research on this group. For example, agri-environmental policy work has built on the behavioural tradition in that there is a research emphasis on the attitudes of the individual, typically male, 'farmer' and his decisionmaking in the business, and less on other farm household members. In contrast, the pluriactivity work has served to widen the focus of attention on other farm household members, including the contribution of farm women (Evans and Ilbery, 1996).

Work on individuals in agricultural research has not been at the expense of that maintaining a more collective focus. Important in this latter respect has been an observable shift in some analyses away from individual people and towards 'agri-cultures' as the 'cultural turn' has impacted upon rural geography. For example, a modified political economy perspective has found 'closer affinities with those concerned with the material and cultural geographies of food and nature' (Whatmore et al., 1996, 55). Some of this work has engaged with Dutch rural sociology on endogenous rural development and 'local knowledge systems' (see Long, 1989; van der Ploeg, 1990 and 1992; Murdoch and Clark, 1994), but has not fully considered these as cultural phenomena. In this latter case, a starting point would be to recognise that farmers are bearers of locally specific knowledge actively shaping the policy context, rather than simply receivers of information from policy-makers as is commonly assumed. Such an important conceptual development is one that is yet to be fully exploited in agricultural research (Winter, 1997).

The insights from cultural perspectives have yet to impact fully on agricultural geography. Rather, a continued evolution of a behaviourally grounded approach in a post-structuralist context can be identified strongly in the main research avenues of pluriactivity and agrienvironmental policy (see Bateman and Ray, 1994; Morris and Potter, 1995; Wilson, 1996). In 
some ways, it is understandable that work has not been more culturally sensitive because much of it has been delivered within a 'policy evaluation' mould. The monitoring brief demanded by government agencies leads inevitably to questionnaire type approaches to inform their policy adjustments, focusing on the 'principal' decision-maker. Despite these limitations, the use of culturally sensitive perspectives has begun to have an impact (McEachern, 1992; McHenry, 1994; Clark, 1994; Young et al., 1995; Morris and Andrews, 1997; Walsh, 1997). This is partly because the AEP shift has an inherent cultural dimension, as exemplified by the ESA approach, the government's flagship AEP (Baldock et al., 1990). These are targeted on specific geographical areas and are sensitive to some of the idiosyncrasies of farming practice founded on local tradition.

Although work has been largely policy-led, there are possibilities for research to commence with cultural constructions of farmers. For example, analyses could begin with well-known constructions of farmers as 'guardians' from the 1942 Scott Report (Ilbery, 1992), as keepers of a 'pastoral myth' (Short, 1991), as 'thieves' of the countryside (Shoard, 1980), or now as 'others' amongst largely non-farming rural populations (Yarwood and Evans, 1998). Alternatively, a decoding of the meanings of 'farmer' could be undertaken on how this group create and interpret understandings of political, social and economic issues, building on the ethnographic approach adopted by Pile (1991) and McEachern (1992). They respectively investigated the political world in which farmers operate and the role of 'conservationist' that a farmer is expected to fulfill. Nevertheless, there has been little debate whether research should start with farming or farmers as cultural constructions, so avoiding a return to a behavioural-type modelling of attitudes and decision-making, or would be better to add in cultural dimensions as an ingredient. Evidence of both approaches can be observed in agriculturally-related work, but not in the explicit way that the exchange of views in rural geography between Philo (1993) and Murdoch and Pratt (1993) about post-modernism and 'post-rurality' might suggest.

The limited impact of the cultural turn in analyses of agricultural change is somewhat surprising given the extent to which rural geography has engaged with cultural geography. This is illustrated by Cloke's (1997) review of the influence of the cultural turn in social science for rural studies. Cultural geographies are identified as inspiring a 'fizz' of interest in 'the rural', but this is yet to permeate 'the agricultural'. Hence, a 'culturally sensitive' agricultural geography offers new conceptual and methodological perspectives on old isses and suggests new topics for inquiry. In short, farmers are still a valuable focus for analysis, but this needs to be complemented by wider views of farming in society. Drawing upon the observations made above, three areas of inquiry immediately present themselves.

1. Greater attention should be paid to cultural constructions of different groups within the farming 'community', which is all too frequently assumed to be homogenous by investigations of non-farming people in rural locales. Certain agricultural groups continue to be neglected despite some recognition within earlier research work, such as farm workers, tenant farmers and women in farming (Newby, 1979; Whatmore, 1991). The value of considering 'others' is already apparent in rural geography, as illustrated by work on new age travellers (Halfacree, 1996) and people of colour (Kinsman, 1995). Further, actor network thinking has stimulated research on the links between farmers and other people, such as agricultural advisors, inspectors and company 
sales representatives, which is deserving of more emphasis (Murdoch and Marsden, 1995; Lowe et al., 1997).

2. Drawing on the work of Short (1991) and Bunce (1994), more work could be attempted on different constructions of farming as an activity, on farmers themselves, and of the places in which farming occurs. A more detailed exploration of the agrarian hyperrealities that are so evident in on-farm recreational pluriactivity is one area worthy of attention in this context. Extending this type of analysis beyond the farm gate to consider images and constructions of food would also be worthwhile (Bell and Valentine, 1997). This approach demands the use of a variety of different media including literary texts and images, film, academic / polemical writing, the national press, policy documents and promotional materials (Cook and Crang, 1996; Mather, 1998; Young and Morris, 1998). Further, constructions of agriculture by groups of countryside users (as opposed to countryside dwellers), such as those of ramblers and mountain-bikers, are relatively unexplored.

3. The geographies of animals has special relevance to agricultural geographers. Astonishingly, animals have almost by 'tradition' been ignored. It can be interpreted as a consequence of human-centredness derived from a sharp dualism in society and nature relations (Murdoch, 1997). Animals are therefore seen as homogenous items of mass production, broad types within policy mechanisms or at best as supplying 'quality products' within the food production system (Yarwood et al., 1998). Little has been written on the association of animals with local folklore and culture, so that a discourse is lacking on the importance of particular animals to particular locales, and to the constructions of these locales. For example, there has been some recognition of the association of sheep with the English Lake District (see Higgins, 1993), but more detailed explorations of the significance breeds of sheep have not been attempted. Only recently has work begun to appreciate the distinctiveness of different breeds of farm livestock in the cultural landscape (Evans and Yarwood, 1995; Yarwood and Evans, 1998). Work which pays greater recognition to the agency of animals, even within an agriculturally domesticated situation is possible (such as the geography of sheep hefts and hefting). Similarly, Philo's (1995) work on exclusion and inclusion offers interesting insights into the microgeography of farming units. Animals were formerly located within farmers' domestic spaces, becoming excluded to adjacent barns over time and in turn increasingly relocated to farmyards from which the residential function has been removed under the influence of farm amalgamation processes.

\section{A future for agricultural research}

Given the political gravity of agrarian questions and their distinctiveness within 'the rural', agriculture should continue to provide a meaningful starting point for debates and research into the next millennium. Identification with agriculture as a starting point for geographical investigations can assist an exploration of changes in the sector itself and in related economic, social, cultural and political activities, as agro-food studies are now acknowledging (Goodman and Watts, 1997). Having established the continued value of an agricultural focus for research, it is evident that since the appearance of Bowler and Ilbery's (1987) paper, the geography of agricultural change has been dominated by a political economy discourse. That a political economy approach has been of enormous value to inform and revitalize agricultural research is 
unquestionable. However, there has been little recent acknowledgement of the value of diversity apparent within agricultural research, apart from reiterations that political economy, as applied in a modified form to agriculture, has sought to accommodate such diversity. This can be viewed as rather disappointing, especially given the discussions that have taken place in rural geography which have propagated a substantial body of new research (Philo, 1993; Murdoch and Pratt, 1993; Cloke, 1997; Phillips, 1998). Clearly, there is a multi-dimensional research agenda in agriculture and so it is difficult to identify one unifying conceptual framework as envisaged by Bowler and Ilbery (1987) or Marsden (1988). It is the range of possible conceptual and empirical positions that allow researchers to appreciate the complexity of old and new agrarian issues preventing any future notion of redundancy in agricultural research.

\section{Notes}

1 GATT refers to the General Agreement of Tariffs and Trade; WTO is the World Trade Organization

\section{References}

Atkins, P. (1988) Redefining agricultural geography as the geography of food. Area 20, 281-283.

Baldock, D., Cox, G., Lowe, P. and Winter, D. (1990) Environmentally Sensitive Areas: incrementalism or reform? Journal of Rural Studies 6, 143-162.

Bateman, D. and Ray, C. (1994) Farm pluriactivity and farm policy: some evidence from Wales. Journal of Rural Studies 10, 1-13.

Battershill, M. and Gilg, A. (1996) Traditional farming and agro-environment policy in southwest England: back to the future? Geoforum 27, 143-147.

Bell, D. and Valentine, G. (1997) Consuming Geographies: we are where we eat. Routledge, London.

Berlan-Darqué, M. and Gasson, R. (1991) Changing gender relations in agriculture: an international perspective. Journal of Rural Studies 7, 1-2.

Bouquet, M. (1985) Family, Servants and Visitors: the farm household in nineteenth and twentieth century Devon. GeoBooks, Norwich.

Bowers, J. and Cheshire, P. (1983) Agriculture, the Countryside and Land Use: an economic critique. Methuen, London.

Bowler, I. (1979) Government and Agriculture: a spatial perspective. Longman, London.

Bowler, I. (1989) Revising the research agenda on agricultural policy in developed market economies. Journal of Rural Studies 5, 385-394. 
Bowler, I. (1992) 'Sustainable agriculture' as an alternative path of farm business development. In Bowler, I., Bryant, C. and Nellis, M. (eds.) Contemporary Rural Systems in Transition, Volume 1: Agriculture and Environment. CAB International, Wallingford, pp.237-253.

Bowler, I. and Ilbery, B. (1987) Redefining agricultural geography. Area 19, 327-332.

Bowler, I. and Ilbery, B. (1993) Sustaining agriculture in the food supply system. In Nellis, D. (ed.) Geographic Perspectives on the Social and Economic Restructuring of Rural Areas. Kansas State University Press, Kansas, USA, pp.4-13.

Brotherton, I. (1991) What limits participation in ESAs? Journal of Environmental Management 32, 241-249.

Bunce, M. (1994) The Countryside Ideal. Routledge, London.

Clark, J. (1994) Strangers in a Strange Land: Farmers and Nature Conservation on the Pevensey Levels. Paper presented at the RESSG Annual Conference, September 14th-16th, Cheltenham and Gloucester College of Higher Education, UK.

Clark, G., Bowler, I., Crockett, A., Ilbery, B. and Shaw, A. (1997) Rural re-regulation and institutional sustainability: a case study of alternative farming systems in England. In Ilbery, B., Chiotti, Q. and Rickard, T. (eds.) Agricultural Restructuring and Sustainability, CAB International, Wallingford, pp.117-134.

Clark, J., Jones, A., Potter, C. and Lobley, M. (1997) Conceptualising the evolution of the European Union's agri-environment policy: a discourse approach. Environment and Planning A $29,1869-1885$.

Cloke, P. (1997) Country backwater to virtual village? Rural studies and 'the cultural turn'. Journal of Rural Studies 13, 367-375.

Cloke, P. and Goodwin, M. (1992) Conceptualizing countryside change: from post-Fordism to structured coherence. Transactions of the Institute of British Geographers 17, 321-336.

Cook, I. and Crang, P. (1996) Amos Gitai's 'Ananas': commodity systems, documentary film making and geographies of displacement. Paper presented at the RGS(IBG) Annual Conference, Strathclyde University, January 3rd-6th.

Cooper, N. (1998) The role of street-level bureaucrats in the implementation of agrienvironmental schemes. Paper presented at the RGS(IBG) Annual Conference, University of Surrey, January 5th-8th.

Cox, G., Lowe, P. and Winter, M. (eds.) (1986) Agriculture: people and policies. Allen and Unwin, London. 
Evans, N. (1997) Something old, new borrowed and blue: the marriage of agriculture and conservation in England. In Ilbery, B., Chiotti, Q. and Rickard, T. (eds.) Agricultural Restructuring and Sustainability, CAB International, Wallingford, pp.117-134.

Evans, N. and Ilbery, B. (1989) A conceptual framework for investigating farm-based accommodation and tourism in Britain. Journal of Rural Studies 5, 257-266.

Evans, N. and Ilbery, B. (1992) Farm-based accommodation and the restructuring of agriculture: evidence from three English counties. Journal of Rural Studies 8, 85-96.

Evans, N. and Ilbery, B. (1993) The pluriactivity, part-time farming and farm diversification debate. Environment and Planning A 25, 945-959.

Evans, N. and Ilbery, B. (1996) Exploring the influence of farm-based pluriactivity on gender relations in capitalist agriculture. Sociologia Ruralis 36, 74-92.

Evans, N. and Morris, C. (1997) Towards a geography of agri-environmental policies in England and Wales. Geoforum 28, 189-204.

Evans, N. and Yarwood, R. (1995) Livestock and landscape. Landscape Research 20, 141-146.

Frankenburg, R. (1966) Communities in Britain. Penguin, Harmondsworth.

Gasson, R. (1980) Roles of farm women in England. Sociologia Ruralis 20, 165-180.

Gasson, R. (1989) Farm Work By Farmers’ Wives. Wye College Farm Business Unit, Occasional Paper No. 15.

Goodman, D. and Watts, M. (1997) Globalising Food: agrarian questions and global restructuring. Routledge, London.

Goodwin, M. and Painter, J. (1996) Local governance, the crises in Fordism and the changing geographies of regulation. Transactions of the Institute of British Geographers 21, 635-648.

Halfacree, K. (1996) Out of place in the country: travellers and the rural idyll. Antipode 28, 4272.

Halfacree, K. (1997) British rural geography: a perspective on the last decade. In Ontiveros, A. and Hernando, F. (eds.) From Traditional Countryside to Postproductivism: recent trends in rural geography research in Britain and Spain. Asociación de Geógrafos Españoles, Murcia, Spain, pp.133-148.

Harper, S. (1989) The British rural community: an overview of perspectives. Journal of Rural Studies 5, 161-184. 
Higgins, D. (1993) The Lake District: the contemporary representation of a valued place as a national institution. Unpublished PhD thesis, University of Exeter, UK.

Ilbery, B. (1985) Agricultural Geography: a social and economic analysis. Oxford University Press, Oxford.

Ilbery, B. (1991) Farm diversification as an adjustment strategy on the urban fringe of the West Midlands. Journal of Rural Studies 7, 207-218.

Ilbery, B. (1992) From Scott to ALURE - and back again? Land Use Policy 9, 131-142.

Ilbery, B. and Bowler, I. (1998) From agricultural productivism to post-productivism. In Ilbery, B. (ed.) The Geography of Rural Change. Longman, London, pp.57-84.

Ilbery, B. and Evans, N. (1996) Post-productive agriculture in the South Midlands. In Bowler, I. (ed.) Progress in Research on Rural Geography. Department of Geography Occasional Paper 35, Leicester University, UK, pp.83-84.

Ilbery, B., Chiotti, Q. and Rickard, T. (eds.) (1997) Agricultural Restructuring and Sustainability. CAB International, Wallingford.

Kinsman, P. (1995) Landscape, race and national identity. Area 27, 300-310.

Le Heron, R. and Roche, M. (1995) A ‘fresh’ place in food's space. Area 27, 23-33.

Long, N. (ed.) (1989) Encounters at the interface: a perspective on social discontinuities in rural development. Wageningen Sociological Studies 27, Wageningen: Agricultural University, Netherlands.

Lowe, P., Cox, G., MacEwen, M., O’Riordan, T. and Winter, M. (1986) Countryside Conflicts: the politics of farming, forestry and conservation. Gower/Maurice Temple Smith, London.

Lowe, P., Murdoch, J., Marsden, T., Munton, R. and Flynn, A. (1993) Regulating the new rural spaces: the uneven development of land. Journal of Rural Studies 9, 205-222.

Lowe, P., Clark, J., Seymour, S. and Ward, N. (1997) Moralizing the Environment. UCL Press, London.

Mather, C. (1998) Re-regulating the South African citrus filiere. Paper presented to the EGRG conference, Manchester University, September 1st-2nd.

Marsden, T. (1988) Exploring political economy approaches in agriculture. Area 20, 315-322.

Marsden, T. (1998a) Agriculture beyond the treadmill? Issues for policy, theory and research practice. Progress in Human Geography 22, 265-275. 
Marsden, T. (1998b) New rural territories: regulating the differentiated rural spaces. Journal of Rural Studies 14, 107-117.

Marsden, T. and Arce, A. (1995) Constructing quality: emerging food networks in the rural transition. Environment and Planning A 27, 1261-1279.

Marsden, T., Munton, R., Whatmore, S. and Little, J. (1986) Towards a political economy of capitalist agriculture: a British perspective. International Journal of Urban and Regional Research 10, 489-521.

Marsden, T., Whatmore, S. and Munton, R. (1987) Uneven development and the restructuring process in British agriculture: a preliminary exploration. Journal of Rural Studies 3, 297-308.

Marsden, T., Munton, R., Whatmore, S. and Little, J. (1989) Strategies for coping in capitalist agriculture: an examination of responses of farm families in British agriculture. Geoforum 20, 114.

Marsden, T., Munton, R., Ward, N. and Whatmore, S. (1996) Agricultural geography and the political economy approach: a review. Economic Geography 72, 361-375.

McEachern, C. (1992) Farmers and conservation: conflict and accommodation in farming politics. Journal of Rural Studies 8, 159-171.

McHenry, H. (1994) Farmers' interpretations of their situation: some implications for environmental schemes. Paper presented to the 35th EAAE Seminar, Aberdeen University, June.

McMichael, P. (ed.) (1993) Agro-food System Restructuring in the Late Twentieth Century: comparative and global perspectives. Cornell University Press, Ithaca, USA.

Morris, C. and Andrews, C. (1997) The construction of environmental meanings within 'farming culture' in the UK: the implications for agri-environmental research. In Ilbery, B., Chiotti, Q. and Rickard, T. (eds.) Agricultural Restructuring and Sustainability. CAB International, Wallingford, pp.87-99.

Morris, C. and Potter, C. (1995) Recruiting the new conservationists: adoption of agrienvironmental schemes in the UK. Journal of Rural Studies 11, 51-63.

Morris, C. and Young, C. (1997) Never mind the environment, feel the 'quality': a discussion of the agri-environmental potential of quality assurance schemes. The North West Geographer, Third Series, 1, 36-47.

Morris, C. and Young, C. (1998) Promoting quality in UK food production: an examination of quality discourses in the UK farming press. Paper presented to the Paper presented at the RGS(IBG) Annual Conference, University of Surrey, January 5th-8th. 
Munton, R. (1990) Farming families in upland Britain: options, strategies and futures. Paper presented to the Association of American Geographers, Toronto.

Murdoch, J. (1997) Inhuman/nonhuman/human: actor-network theory and the prospects for a nondualistic and symmetrical perspective on society and nature. Environment and Planning D, Society and Space 15, 731-756.

Murdoch, J. and Clark, J. (1994) Sustainable knowledge. Geoforum 25, 115-132.

Murdoch, J. and Marsden, T. (1995) The spatialization of politics: local and national actor-spaces in environmental conflict. Transactions of the Institute of British Geographers 20, 368-380.

Murdoch, J. and Pratt, A. (1993) Rural Studies: modernism, postmodernism and the 'post-rural'. Journal of Rural Studies 9, 411-427.

Murdoch, J. and Ward, N. (1997) Governmentality and territoriality: the statistical manufacture of Britain's ‘national farm'. Political Geography 16, 307-324.

Newby, H. (1979) Green and Pleasant Land: social change in rural England. Hutchinson, London.

Phillips, M. (1998) The restructuring of social imaginations in rural geography. Journal of Rural Studies 14, 121-153.

Philo, C. (1993) Postmodern rural geography? A reply to Murdoch and Pratt. Journal of Rural Studies 9, 429-436.

Philo, C. (1995) Animals, geography and the city: notes on inclusions and exclusions. Environment and Planning D: Society and Space 13, 655-681.

Pile, S. (1991) 'A load of bloody idiots': Somerset dairy farmers' view of their political world. Political Geography Quarterly 10, 405-421.

van der Ploeg, J. (1990) Labour Markets and Agricultural Production. Westview Press, Boulder, USA.

van der Ploeg, J. (1992) The reconstitution of locality: technology and labour in modern agriculture. In Marsden, T., Lowe, P. and Whatmore, S. (eds.) Labour and Locality. David Fulton, London, pp.19-43.

Potter, C. (1988) Environmentally Sensitive Areas in England and Wales: an experiment in countryside management. Land Use Policy 5, 301-313. 
Potter, C. (1998) Against the Grain: agri-environmental policy reform in the US and EU. CAB International, Wallingford.

Potter, C. and Goodwin, P. (1998) Agricultural liberalisation in the European Union: an analysis of the implications for nature conservation. Journal of Rural Studies 14, 287-298.

Robinson, G. (1991) EC agricultural policy and the environment: land use implications in the UK. Land Use Policy 8, 95-107.

Shoard, M. (1980) The Theft of the Countryside. Temple Smith, London.

Short, D. (1996) Subsuming the family farm: from land use study to political economy in rural geography. Scottish Geographical Magazine 112, 51-53.

Short, J. (1991) Imagined Country. Routledge, London.

Skerratt, S. (1994) Itemized payments within a scheme: the case of Breadalbane. In Whitby, M. (ed.) Incentives for Countryside Management. CAB International, Wallingford, pp.105-133.

Walsh, M. (1997) The view from the farm: farmers and agri-environmental schemes in the Yorkshire Dales. The North West Geographer, Third Series, 1, 24-35.

Ward, N. (1993) The agricultural treadmill and the rural environment in the post-productivist era. Sociologia Ruralis 33, 348-364.

Ward, N., Lowe, P., Seymour, S. and Clark, J. (1995) Rural restructuring and the regulation of farm pollution. Environment and Planning A 27, 1193-1211.

Whatmore, S. (1991) Farming Women. Macmillan, Basingstoke.

Whatmore, S. (1993) Agricultural geography. Progress in Human Geography 17, 84-91.

Whatmore, S. (1995) From farming to agribusiness: the global agro-food system. In Johnston, R., Taylor, P. and Watts, M. (eds.) Geographies of Global Change. Blackwell, Oxford, pp.36-49.

Whatmore, S., Munton, R., Marsden, T., and Little, J. (1996) The trouble with subsumption and other rural tales: a response to critics. Scottish Geographical Magazine 112, 54-56.

Whitby, M. (ed.) (1994) Incentives for Countryside Management. CAB International, Wallingford.

Wilson, G. (1996) Farmer environmental attitudes and ESA participation. Geoforum 27, 115131. 
Wilson, G. (1997) Factors influencing farmer participation in the Environmentally Sensitive Areas scheme. Journal of Environmental Management 50, 67-93.

Winter, M. (1996) Rural Politics: policies for agriculture, forestry and the environment. Routledge, London.

Winter, M. (1997) New policies and new skills: agricultural change and technology transfer. Inaugural Lecture, Cheltenham and Gloucester College of Higher Education, January 30th.

Yarwood, R. and Evans, N. (1998) The changing geographies of domestic livestock animals. Society and Animals 6, 137-166.

Yarwood, R., Evans N. and Higginbottom, J. (1998) From market place to marketing place: rare livestock breeds and countryside change. Paper presented at the RGS(IBG) Annual Conference, University of Surrey, January 5th-8th.

Young, C. and Morris, C. (1998) New geographies of agro-food production: an analysis of UK quality assurance schemes. Paper presented to the EGRG conference, Manchester University, September 1 st-2nd.

Young, C., Morris, C. and Andrews, C. (1995) Agriculture and the environment in the UK: towards an understanding of the role of farming culture. Greener Management International 12, 63-80. 